\title{
HUBUNGAN POLA PEMBERIAN MAKANAN \\ DENGAN STATUS GIZI BALITA UMUR 1-5 TAHUN \\ DI DESA NGAMPEL KULON KECAMATAN NGAMPEL KABUPATEN KENDAL
}

\author{
Jumiatun $^{1}$ \\ Email : jumiatununiska@gmail.com \\ Stikes Uniska Kendal \\ Jl.Soekarno Hatta No 99 Kendal \\ Telp/Fax (0294) 381299
}

\begin{abstract}
Abstrak
Periode paling penting pertumbuhan dan perkembangan terjadi pada masa balita. Malnutrisi berat dapat menyebabkan gizi kurang seringkali diikuti dengan rendahnya perkembangan mental dan fisik secara tetap sebagai akibat dari masalah gizi kronis. Keadaan gizi yang baik dan sehat pada masa balita merupakan fondasi penting bagi kesehatannya di masa depan. Di Indonesia, 193 ribu anak balita meninggal pertahun disebabkan oleh penyakit infeksi dan masalah gizi. Kesukaan anak akan jajanan ringan menyebabkan kebutuhan energi sehari-hari mereka tidak terpenuhi. Akibat dari pemberian pola makanan yang salah mengakibatkan gizi kurang pada balita yang dapat berdampak terhadap pertumbuhan dan perkembangan fisik maupun mentalnya. Penelitian ini bertujuan menganalisis hubungan pola pemberian makanan dengan status gizi balita umur 1-5 tahun di desa Ngampel Kulon Kecamatan Ngampel Kabupaten Kendal. Jenis penelitian survey analitik dengan desain case control. Populasi penelitian balita di desa Ngampel Kulon kecamatan Ngampel. Besar sampel yang diambil 77 melalui teknik simple random sampling. Pengujian hipotesis menggunakan analisis uji chi square untuk mengetahui hubungan pola pemberian makanan dengan status gizi. Hasil penelitian menunjukkan ada hubungan yang signifikan antara pola pemberian makanan dengan status gizi balita umur 1 - 5 tahun di desa Ngampel Kulon kecamatan Ngampel dengan p value 0,003.
\end{abstract}

Kata kunci: pola pemberian makanan, status gizi, balita

\section{Pendahuluan}

Periode paling penting pertumbuhan dan perkembangan terjadi pada masa balita ${ }^{(1)}$. Sekitar 200 juta anak di bawah umur 5 tahun gagal untuk mencapai potensi mereka dalam perkembangan kognitif karena berbagai macam faktor risiko seperti kemiskinan, kesehatan yang rendah, pola asuh dan gizi yang tidak mencukupi ${ }^{(2)}$. Malnutrisi berat dapat menyebabkan gizi kurang (berat badan rendah menurut umur, seringkali dikaitkan dengan kehilangan lemak dan jaringan otot yang disebabkan oleh kelaparan akut) dan stunting (tinggi badan yang rendah menurut umur, seringkali diikuti dengan rendahnya perkembangan mental dan fisik secara tetap sebagai akibat dari masalah gizi kronis ${ }^{(3)}$.

Proses pertumbuhan yang dialami oleh balita merupakan hasil kumulatif sejak balita tersebut dilahirkan. Keadaan gizi yang baik dan sehat pada masa balita (umur bawah lima tahun) merupakan fondasi penting bagi kesehatannya di masa depan. Kondisi yang berpotensi mengganggu pemenuhan zat gizi terutama energi dan protein pada anak akan menyebabkan masalah gangguan
pertumbuhan $^{(3)}$.

Negara - Negara di seluruh dunia berkomitmen untuk mempercepat pembangunan manusia dan pemberantasan kemiskinan. Komitmen tersebut dikenal dengan Millenium Development Goals $(M D G$ 's). Salah satu program penting dalam mencapai MDGs adalah perbaikan gizi. Gizi yang baik membuat kontribusi penting untuk memerangi kemiskinan, melindungi dan meningkatkan kesehatan, mengurangi kematian terutama dikalangan ibu dan anak (4).

Di Indonesia, 193 ribu anak balita meninggal pertahun disebabkan oleh penyakit infeksi dan masalah gizi. Selain itu, terjadi kesenjangan cukup tinggi angka kematian balita yang terdapat di seperlima dari wilayah termiskin (190 per 1000 kelahiran hidup) dan seperlima dari wilayah terkaya (29 per 1000 kelahiran hidup) ${ }^{(5)}$.

Masalah gizi pada hakikatnya adalah masalah kesehatan masyarakat, namun penangulangannya tidak dapat dilakukan 
dengan pendekatan medis dan pelayanan kesehatan. Penyebab masalah kesehatan gizi ini berbagai multifator, oleh karena itu pendekatan penanggulangan harus melibatkan berbagai sektor yang terkait ${ }^{(6)}$.

Masalah gizi sering berkaitan dengan masalah kekurangan pangan, pemecahan tidak selalu berupa peningkatan produksi dan pengadaan pangan. Pada kasus tertentu, seperti dalam keadaan krisis (bencana kekeringan, kekacauan sosial, krisis ekonomi), masalah gizi muncul akibat masalah ketahanan pangan di tingkat rumah tangga, yaitu kemampuan rumah tangga memperoleh makanan untuk semua anggota keluarganya. Dalam konteks itu masalah gizi tidak lagi semata-mata masalah kesehatan tetapi masalah kemiskinan, pemerataan, dan masalah kesempatan kerja ${ }^{(6)}$.

Faktor yang menyebabkan kurang gizi pada balita yaitu penyebab langsung dan tidak langsung. Penyebab langsung yaitu makanan anak dan penyakit infeksi yang diderita anak. Sedangkan penyebab tidak langsung yaitu ketahanan pangan di keluarga, pola asuh anak, pelayanan kesehatan, dan kesehatan lingkungan ${ }^{(7)}$.

Upaya perbaikan/peningkatan gizi dilakukan dengan cara memenuhi kebutuhan gizi anak salah satunya melalui pengaturan pola makan. Asupan gizi seimbang dari makanan memegang peranan penting dalam proses pertumbuhan anak dibarengi dengan pola makan yang baik dan teratur yang perlu diperkenalkan sejak dini, antara lain dengan perkenalan jam-jam makan dan variasi makanan dapat membantu mengkoordinasikan kebutuhan akan pola makan sehat pada anak ${ }^{(8)}$.

Sumber gizi yang utama berasal dari makanan yang bergizi yang merupakan modal utama dalam perkembangan tubuh terutama bagi bayi dan balita. Makanan bergizi tidak hanya menentukan kesehatan tubuh bayi dan balita di kemudian hari, tetapi juga kecerdasan otak. Memberikan makanan pada balita harus selalu dimulai secara bertahap sedikit demi sedikit, baik dalam jumlah porsi maupun kekentalan tekstur makanannya. Sebaiknya makanan diberikan pada saat sedang lapar. Jangan pula memaksa anak untuk makan, karena akan mengakibatkan gangguan nafsu makan bahkan Anoreksia ${ }^{(7)}$.
Kebiasaan makan yang jelek pada anak dibawah umur 5 tahun sering dapat dilacak secara langsung pada faktor orang tua, perhatian yang kurang darinya mengenai kuantitas dan kualitas diet merupakan faktor yang sering ditemukan. Perilaku dan kebiasaan orang tua dalam hal makanan yang dipengaruhi oleh faktor budaya dan mempengaruhi sikap suka dan tidak suka seorang anak terhadap makanan ${ }^{(9)}$.

Pola pemberian makanan pada anak usia 1-5 tahun berbeda dengan orang dewasa. Batasi penggunaan garam dan gula yang berlebihan. Konsumsi garam untuk balita tidak lebih dari 1/6 jumlah maksimum orang dewasa sehari atau kurang dari 1 gram. Kadang makanan orang dewasa terlalu banyak garam dan gula, bahkan mengandung bahan pengawet atau pewarna buatan. Porsi makan anak juga berbeda dengan orang dewasa, mereka membutuhkan makanan sumber energi yang lengkap gizi dalam jumlah lebih kecil namun sering. Kesukaan anak akan jajanan ringan menyebabkan kebutuhan energi sehari-hari mereka tidak terpenuhi. Padahal bahan makanan sumber energi seperti karbohidrat, protein, mineral, lemak serta vitamin, mineral dan serat wajib dikonsumsi anak setiap hari. Akibat dari pemberian pola makanan yang salah mengakibatkan gizi kurang pada balita yang dapat berdampak terhadap pertumbuhan dan perkembangan fisik maupun mentalnya. Anak akan terlihat pendek, kurus dan ketika memasuki usia sekolah mereka tidak dapat berprestasi menonjol karena kecerdasaan otaknya terganggu ${ }^{(7)}$.

Tujuan penelitian ini adalah menganalisis hubungan antara pola pemberian makanan dengan status gizi balita umur 1-5 tahun di desa Ngampel Kulon Kecamatan Ngampel Kabupaten Kendal.

\section{Status Gizi}

Status gizi adalah keadaan tubuh sebagai akibat dari konsumsi makanan dan penggunaan zat - zat bergizi ${ }^{(10)}$.

Penilaian status gizi secara langsung dapat menggunakan penilaian antropometri. Parameter antropometri merupakan dasar dari penilaian status gizi. Kombinasi antara beberapa parameter disebut indeks antropometri, antara lain Berat Badan menurut Umur $(\mathrm{BB} / \mathrm{U})$. Tinggi badan 
menurut Umur $(\mathrm{TB} / \mathrm{U})$, dan Berat Badan per Tinggi Badan $(\mathrm{BB} / \mathrm{TB})^{(6)}$.

Pengukuran status gizi dapat juga mengunakan Kartu Menuju Sehat (KMS). Klasifikasi status gizi pada balita berdasarkan Kartu Menuju Sehat sebagai berikut ${ }^{(11)}$ :

a. Gizi Lebih : jika hasil penimbangan berat badan berada pada garis pertumbuhan diatas pita warna hijau.

b. Gizi Baik : jika hasil penimbangan berat badan berada pada garis pertumbuhan di pita warna hijau.

c. Gizi Kurang : jika hasil penimbangan berat badan berada pada garis pertumbuhan di pita warna kuning.

d. Gizi Buruk : jika hasil penimbangan berat badan berada pada garis pertumbuhan dipita warna bawah garis merah.

Beberapa masalah gizi yang sering terjadi pada balita antara lain ${ }^{(12)}$ :

a. Gizi lebih.

Gizi lebih biasanya disebabkan karena kelebihan masukan makanan bukannya dari kelebihan makan (overeating). Simpanan lemak dalam tubuh bertambah ketika masukan energi melebihi pengeluaran, dan keadaan ini biasanya terjadi bila ada keseimbangan energi yang sedikit positif selama masa yang lama. Anak gemuk tidak makan secara berbagai atau lebih banyak makan "junk food" atau tepung dari pada sebayanya. Pengeluaran energi total selama latihan fisik anak gemuk terkontrol bertambah, tetapi bila dikoreksi menurut kenaikan massa tubuh adalah ekuivalen dengan pengeluaran energi total anak tidak gemuk (nonobese). Angka metabolik juga sama bila disesuaikan dengan massa tubuh yang aktif secara metabolik.

Nafsu makan dapat mempengaruhi oleh berbagai faktor yang meliputi gangguan psikologis, lesi hipotalamus, pituitari, atau lesi otak lain dan hiperinsulinisme. Predisposisi obesitas bisa diakibatkan dari faktor genetik maupun lingkungan, tapi faktor lingkungan yang lebih mempengaruhi terjadinya obesitas.

b. Gizi kurang

Gizi kurang adalah gangguan kesehatan akibat kekurangan atau ketidakseimbangan zat gizi yang diperlukan untuk pertumbuhan dan perkembangan balita.

Gizi kurang dibagi menjadi 3 yaitu $^{(13)}$

1) Kekurangan energi protein ringan. KEP ringan bila hasil penimbangan berat badan pada KMS terletak pada pita warna kuning.

2) Kekurangan energi protein sedang. KEP sedang bila hasil penimbangan berat badan pada KMS terletak dibawah garis merah. Selain itu, ada tanda yang bisa dilihat dengan jelas adalah wajah menjadi pucat, dan warna rambut berubah agak kemerahan.

3) Kekurangan energi protein berat.

a) Marasmus

Berat badan anak hanya mencapai 60 persen atau kurang dari berat badan normal Marasmus ditandai dengan ${ }^{(6)}$ :

(1) Anak tampak sangat kurus.

(2) Wajah seperti orang tua.

(3) Cenggeng, rewel.

(4) Kulit keriput, jaringan lemak subkutis sangat sedikit, bahkan sampai tidak ada.

(5) Sering disertai diare kronik atau konstipasi / susah buang air besar serta penyakit kronik.

(6) Tekanan darah, detak jantung dan pernafasan berkurang.

b) Kwashiorkor.

Tanda-tanda dari kwashiorkor ${ }^{(6)}$

(1) Odem umumnya diseluruh tubuh dan terutama pada kaki (dorsum pedis).

(2) Wajah membulat dan sembab.

(3) Otot-otot mengecil, lebih nyata apabila diperiksa pada posisi berdiri dan duduk, anak berbaring terus menerus.

(4) Perubahan status mental : cengeng, rewel kadang apatis.

(5) Anak sering menolak segala jenis makanan (anoreksia).

(6) Pembesaran hati. 
(7) Sering disertai infeksi, anemia dan diare / mencret.

(8) Rambut berwarna kusam dan mudah dicabut.

(9) Gangguan kulit berupa bercak merah yang meluas dan berubah menjadi hitam terkelupas (crazy pavement dermatosis).

(10) Pandangan mata anak nampak sayu.

c) Marasmus-kwashiorkor.

Tanda-tanda marasmuskwashiorkor adalah gabungan dari tanda-tanda yang ada pada marasmus dan kwashiorkor.

\section{c. Gizi Buruk}

Status kondisi seseorang yang kekurangan nutrisi, atau nutrisinya dibawah standar rata-rata. Gizi buruk ini biasanya terjadi pada anak balita (bawah lima tahun) dan ditampakkan oleh membusungnya perut (busung lapar). Gizi buruk dapat berpengaruh kepada pertumbuhan dan perkembangan anak, juga kecerdasan anak. Pada tingkat yang lebih parah, jika dikombinasikan dengan perawatan yang buruk, sanitasi yang buruk, dan munculnya penyakit lain. Gizi buruk dapat menyebabkan kematian.

Gizi buruk disebabkan oleh beberapa faktor yaitu $^{(13):}$

1) Faktor pengadaan makanan yang kurang mencukupi suatu wilayah tertentu. Hal ini bisa disebabkan oleh kurangnya potensi alam atau kesalahan distribusi.

2) Segi kesehatan sendiri, yakni adanya penyakit kronis terutama gangguan pada metabolisme atau penyerapan makanan.

Ada tiga hal yang saling berkaitan dalam hal gizi buruk, yaitu kemiskinan, pendidikan rendah, dan kesempatan kerja rendah. Tiga hal itu mengakibatkan kurangnya ketersediaan pangan dirumah tangga dan pola asuh anak keliru. Hal ini mengakibatkan kurangnya asupan gizi dan balita sering terkena infeksi penyakit.

d. Gizi lebih.

Gizi lebih biasanya disebabkan karena kelebihan masukan makanan bukannya dari kelebihan makan (overeating). Simpanan lemak dalam tubuh bertambah ketika masukan energi melebihi pengeluaran, dan keadaan ini biasanya terjadi bila ada keseimbangan energi yang sedikit positif selama masa yang lama. Anak gemuk tidak makan secara berbagai atau lebih banyak makan "junk food" atau tepung dari pada sebayanya. Pengeluaran energi total selama latihan fisik anak gemuk terkontrol bertambah, tetapi bila dikoreksi menurut kenaikan massa tubuh adalah ekuivalen dengan pengeluaran energi total anak tidak gemuk (nonobese). Angka metabolik juga sama bila disesuaikan dengan massa tubuh yang aktif secara metabolik.

Nafsu makan dapat mempengaruhi oleh berbagai faktor yang meliputi gangguan psikologis, lesi hipotalamus, pituitari, atau lesi otak lain dan hiperinsulinisme. Predisposisi obesitas bisa diakibatkan dari faktor genetik maupun lingkungan, tapi faktor lingkungan yang lebih mempengaruhi terjadinya obesitas ${ }^{(12)}$.

Faktor-faktor yang mempengaruhi status gizi pada balita ${ }^{(14)}$

a. Penyebab langsung

Status gizi yang dipengaruhi oleh penyebab langsung meliputi makanan anak dan penyakit infeksi yang mungkin diderita anak.

b. Penyebab tidak langsung

Status gizi yang dipengaruhi oleh penyebab tidak langsung meliputi ketahanan pangan dikeluarga, pola pengasuhan anak, serta pelayanan kesehatan dan lingkungan.

\section{Pola makan}

Pola makan adalah berbagai informasi yang memberikan gambaran mengenai macam, jumlah dan frekuensi bahan makanan yang dimakan setiap hari oleh orang dan merupakan ciri khas untuk suatu kelompok masyarakat tertentu ${ }^{(9)}$.

Syarat pola makan pada balita ${ }^{(15)}$ :

a. Cukup kalori sesuai umur dan berat badannya.

b. Cukup vitamin, mineral dan zat gizi lain yang dibutuhkan oleh tubuh.

c. Tiddeak merangsang atau berbumbu tajam.

d. Tidak terlalu berlemak atau gorengan. 
e. Tidak terlalu manis.

f. Menu bervariasi, dihidangkan secara menarik agar nafsu makannya meningkat.

Masalah gizi yang timbul pada balita umur 15 tahun ada empat masalah antara lain ${ }^{(16)}$ :

a. penolakan terhadap makan, sulit makan, hanya sedikit makanan yang dimakan atau pilih-pilih makanan.

b. Kebiasaan makan camilan bersama dengan waktu makan dapat mengurangi nafsu makan.

c. Tingginya konsumsi jus buah atau minuman ringan.

d. Tingginya konsumsi camilan seperti kue, biskuit, kripik, chiki-chiki, kudapan manis dan permen

\section{Metode Penelitian}

Penelitian ini merupakan penelitian survey analitik dengan desain case control. Penelitian dilakukan di desa Ngampel Kulon kecamatan Ngampel kabupaten Kendal. Berdasarkan hasil survey jumlah balita di desa Ngamel Kulon sebanyak 257 balita. Balita dengan gizi kurang dan BGM sejumlah 104 dan balita dengan gizi baik sejumlah 153. Sampel diambil secara acak sederhana sejumlah 77 balita.

Pada penelitian ini jenis data yang digunakan adalah data primer dan sekunder. Data primer diperoleh dari kuesioner yang terdiri dari umur ibu, pendidikan terakhir ibu, jumlaah anak dan pola pemberian makan balita sesuai umur, sedangkan status gizi balita diperoleh dari hasil penimbangan, dengan penilaian status gizi berdasarkan grafik pada KMS. Data sekunder berupa jumlah balita yang diperoleh dari puskesmas Ngampel.

Teknik analisis data menggunakan analisis data deskriptif untuk menggambarkan variabel pola pemberian makan dan status gizi. Pengujian hipotesis menggunakan uji chi-square untuk melihat hubungan dua variabel yang berbeda dengan tingkat kepercayaan 95\% untuk mengetahui hubungan pola pemberian makanan dengan status gizi.

\section{Hasil dan Pembahasan}

Pada penelitian ini, karateristik ibu balita dilihat dari umur, pendidikan dan jumlah anak. Pada kelompok kasus, umur ibu mayoritas pada kelompok umur 20-35 tahun sebanyak $80,6 \%$, pendidikan ibu mayoritas
SMP $(58,1 \%)$ dan jumlah anak mayoritas pada kelompok multipara $(58,1 \%)$. Karakteristik ibu pada kelompok kontrol juga menunjukkan hasil yang tidak berbeda, umur ibu mayoritas pada kelompok umur 20-35 tahun sebanyak $82,6 \%$, pendidikan ibu mayoritas SMP $(43,4 \%)$ dan jumlah anak mayoritas pada kelompok multipara $(60,9 \%)$. Pola pemberian makan pada kelompok kasus mayoritas dalam kategori cukup $(45,2 \%)$, kurang 25,8\% dan baik 29\%. Sedangkan pada kelompok kontrol pola pemberian makan mayoritas dalam kategori baik $(65,2 \%)$, cukup $28,3 \%$ dan kurang 6,5\%.

Tabel 1. Distribusi Frekuensi Pola Pemberian Makanan Pada Balita

\begin{tabular}{lcccc}
\hline \multirow{2}{*}{$\begin{array}{c}\text { Pola Pemberian } \\
\text { Makan }\end{array}$} & \multicolumn{2}{c}{ Kasus } & \multicolumn{2}{c}{ Kontrol } \\
\cline { 2 - 5 } & $\mathrm{f}$ & $\%$ & $\mathrm{f}$ & $\%$ \\
\hline Baik & 9 & 29 & 30 & 65,2 \\
Cukup & 14 & 45,2 & 13 & 28,3 \\
Kurang & 8 & 25,8 & 3 & 6,5 \\
\hline Total & 31 & 100 & 46 & 100 \\
\hline
\end{tabular}

Tabel 2. Hubungan Pola Pemberian Makanan dengan Status Gizi

\begin{tabular}{ccccccccc}
\hline \multirow{2}{*}{$\begin{array}{c}\text { Pola } \\
\text { Makan }\end{array}$} & \multicolumn{9}{c}{ Baik } & \multicolumn{2}{c}{ Kurang } & \multicolumn{2}{c}{ Buruk } & \multirow{2}{*}{ Total } \\
\cline { 2 - 7 } & $\mathrm{f}$ & $\%$ & $\mathrm{f}$ & $\%$ & $\mathrm{f}$ & $\%$ & $\mathrm{f}$ & $\%$ \\
\hline Baik & 30 & 39 & 8 & 10,4 & 1 & 1,3 & 39 & 50,6 \\
Cukup & 13 & 16,9 & 9 & 11,7 & 5 & 6,5 & 27 & 35,1 \\
Kurang & 3 & 3,9 & 5 & 6,5 & 3 & 3,9 & 11 & 14,3 \\
\hline Jumlah & 46 & 59,7 & 22 & 28,6 & 9 & 11,7 & 77 & 100 \\
\hline P value $=0,003$ & \multicolumn{10}{c}{$=0$}
\end{tabular}

Latar belakang pendidikan seseorang merupakan salah satu unsur penting yang dapat mempengaruhi keadaan gizi karena dengan tingkat pendidikan yang lebih tinggi diharapkan pengetahuan atau informasi tentang gizi yang dimiliki menjadi lebih baik. Seorang dengan pendidikan rendah belum tentu kurang mampu menyusun makanan yang memenuhi persyaratan gizi dibandingkan dengan orang lain yang pendidikannya lebih tinggi. Karena sekalipun berpendidikan rendah, kalau orang tersebut rajin mendengarkan atau melihat informasi mengenai gizi, bukan mustahil pengetahuan gizinya akan lebih baik ${ }^{(17)}$. Ibu yang berpendidikan dasar belum tentu memiliki anak dengan status gizi kurang, mungkin sudah mendapatkan pendidikan gizi dari petugas puskesmas maupun posyandu dan menerapkannya dalam pola pemberian makan pada balitanya. 
Kesehatan tubuh anak sangat erat kaitannya dengan makanan yang dikonsumsi. Zat-zat yang terkandung dalam makanan yang masuk dalam tubuh sangat mempengaruhi kesehatan ${ }^{(18) .}$

Faktor yang cukup dominan yang menyebabkan keadaan gizi kurang meningkat ialah perilaku memilih dan memberikan makanan yang tidak tepat kepada anggota keluarga termasuk anak-anak $^{(19)}$.

Masalah gizi yang timbul pada balita umur 1-5 tahun ada empat masalah antara lain : penolakan terhadap makan, sulit makan, hanya sedikit makanan yang dimakan atau pilih-pilih makanan, kebiasaan makan camilan bersama dengan waktu makan dapat mengurangi nafsu makan, tingginya konsumsi jus buah atau minuman ringan, tingginya konsumsi camilan seperti kue, biskuit, kripik, chiki-chiki, kudapan manis dan permen ${ }^{(16)}$.

Pada penelitian ini, pola pemberian makan yang kurang disebabkan karena sebagian besar ibu tidak memberikan susu kepada balita setiap harinya, ibu tidak memberikan sayuran dalam setiap penyajian makan pada anak, ibu tidak memberikan protein hewani seperti telur, ikan atau daging. Jumlah pemberian makanan, anak tidak dapat menghabiskan 2 porsi piring nasi perhari, anak tidak dapat menghabiskan 1 gelas susu setiap harinya, anak tidak dapat menghabiskan 1 mangkuk sayur perhari.

Akibat dari pemberian pola makanan yang salah mengakibatkan gizi kurang pada balita yang dapat berdampak terhadap pertumbuhan dan perkembangan fisik maupun mentalnya. Anak akan terlihat pendek, kurus dan ketika memasuki usia sekolahpun mereka tidak dapat berprestasi menonjol karena kecerdasaan otaknya terganggu ${ }^{(7)}$.

Hasil penelitian ini sesuai dengan penelitian yang dilakukan oleh Waladow, G tentang hubungan pola makan dengan status gizi pada anak usia 3-5 tahun di wilayah kerja Puskesmas Tompaso yang dinyatakan ada hubungan pola makan dengan status gizi pada anak usia 3-5 tahun di wilayah kerja Puskesmas Tompaso dengan $\mathrm{p}=0,00$.

Dalam penelitian Dina (2011) dikatakan bahwa upaya untuk mengatasi gizi yang sangat penting adalah dengan pengaturan pola makan. Pola yang diterapkan dengan baik dan tepat sangat penting untuk membantu mengatasi masalah gizi yang sangat penting bagi pertumbuhan balita. Ditambah dengan asupan gizi yang benar maka status gizi yang baik dapat tercapai.

\section{Kesimpulan}

Berdasarkan hasil penelitian pada 77 responden tentang hubungan pola pemberian makanan dengan status gizi balita umur $1-5$ tahun di desa Ngampel Kulon kecamatan Ngampel didapatkan kesimpulan bahwa pola pemberian makan pada balita mayoritas baik $(50,6 \%)$, ada hubungan yang signifikan antara pola pemberian makanan dengan status gizi balita umur $1-5$ tahun di desa Ngampel Kulon kecamatan Ngampel dengan $\mathrm{p}$ value 0,003 .

\section{Daftar Pustaka}

[1] Adriani, M. \& Wirjatmadi, B. Gizi dan Kesehatan Balita Peranan Mikro Zink Pada Pertumbuhan Balita. Kencana Prenadamedia Group. 2014.

[2] Grantham-mcgregor, S. et al. Child development in developing countries 1 Developmental potential in the fi rst 5 years for children in. Lancet 369, 60-70. 2007.

[3] Hermina, Prihatini, S. Gambaran Keragaman Makanan dan Sumbangannya Terhadap Konsumsi Energi Protein Pada Anak Balita Pendek (Stunting) di Indonesia. Puslitbang Gizi dan Makanan, Badan Litbangkes Kemenkes RI. Jurnal Badan Litbangkes, Vol.39, No 2, hal 62-73. 2011.

[4] Nila, F.M. Peran Sektor Swasta Dalam Mencapai MDGS.2011. (http://www.wartaekonomi.co.id).

[5] Cahyani, E. Target Pencapaian MDGs 2015 Bisa Tidak Terpenuhi. Jurnal Nasional. (http://www.mdgs2015.com).

[6] Supariasa, dkk. Penilaian Status Gizi. Jakarta; EGC.2012.

[7] Sudayasa, P. Bahan Seminar Akhir Studi Faktor - Faktor Penyebab Kekurangan Gizi Anak. (http://doktersehat.com). 2010.

[8] Waladow, G., Warouw, S. M., \& Rottie, J. V. Hubungan Pola Makan Dengan 
Status Gizi Pada Anak Usia 3-5 tahun di Wilayah Kerja Puskesmas Tompaso Kecamatan Tompaso. Ejournal Keperawatan, Volume 1 Nomor 1.2013.

[9] Sulistyoningsih, H. Gizi Untuk Kesehatan Ibu dan Anak. Yogyakarta; Graha Ilmu. 2011.

[10] Almatsier, S. Prinsip Ilmu Gizi Dasar. Jakarta; Gramedia. 2009.

[11] Depkes RI. Status Gizi Versi KMS. (http://cresoft,.com/ 2010/10/01/status_ gizi_versi_KMS). 2005.

[12] Santoso, dkk. Kesehatan dan Gizi. Jakarta; Rineka Cipta. 2009.

[13] Siswono. 2 dari 10 Balita Menderita Gizi Kurang. (http://www.mediaindo.co.id). 2005.

[14] Waryana. Gizi Reproduksi. Yogyakarta; Pustaka Rihana. 2010.

[15] Ardina, A. Anak Susah Makan Apa Solusinya. (http://www.anaksusah makan.co.id).

[16] Andriyani, D. 2013. Kebutuhan Nutrisi dan Jadwal Makan Anak 1-5 Tahun. (http://www.kebutuhannutrisianak15tahun.com). 2013.

[17] Departemen Gizi, Kesehatan Masyarakat FKM UI. Gizi dan Kesehatan Masyarakat. Jakarta; PT Raja Grafindo Persada. 2010.

[18] Prasetyawati, Kesehatan Ibu dan Anak (KIA) Dalam Millenium Development Goals (MDGs). Yogyakarta; Aulia Medika. 2012.

[19] Kementerian Kesehatan RI. Buku Panduan Kader Posyandu Menuju Keluarga Sadar Gizi. Jakarta; Direktorat Bina Gizi. 2011.

[20] Dina,A.A.Nur. Hubungan Pola Makan Dengan Status Gizi Balita di Kelurahan Tanggung Kecamatan Kepanjen Kidul kota Blitar (Studi pada Balita Umur 24-60 bulan). Malang; Universitas Negeri Malang. 2011. 